\title{
Ecological and evolutionary implications of the larval transport and reproductive strategy of bluefish Pomatomus saltatrix
}

\author{
Jonathan A. Hare, Robert K. Cowen \\ Marine Sciences Research Center, State University of New York at Stony Brook, Stony Brook, New York 11794-5000, USA
}

\begin{abstract}
The current view of bluefish Pomatomus saltatrix life history holds that there are 2 distinct spawning events along the east coast of the United States which result in the recruitment of 2 juvenile cohorts to estuaries of the Middle Atlantic Bight. This two-spawning hypothesis is examined through an analysis of gonosomatic indices, larval abundances and larval distributions from both the South Atlantic and Middle Atlantic Bights. These data suggest that bluefish spawn continuously from about March to at least September, rather than in 2 distinct episodes. This continuous-spawning hypothesis raises the problem of which processes could act between spawning and estuarine recruitment to create the appearance of 2 juvenile cohorts. A model is developed which is based on large-scale circulation features of the east coast of the United States and on the hypothesis that bluefish spawn continuously as they migrate northward along the coast. The model predicts that offspring spawned in the middle of the spawning season will have a lower probability of recruitment, thereby creating a bimodal pattern of offspring survival. These results are discussed both in terms of variations in the large-scale circulation which may be responsible for creating intra- and interannual variation in recruitment, and in terms of the apparent non-adaptive nature of bluefish reproductive strategy.
\end{abstract}

\section{INTRODUCTION}

Since Hjort (1914), transport has been recognized as influencing the dynamics of early life history stages of marine organisms through the movement of offspring away from areas necessary for, or favorable to, survival (see Sinclair 1988). Many species require that their planktonic offspring be returned to settlement sites appropriate for adult stages (Jackson \& Strathmann 1981, Cowen 1985). If offspring are not transported to these specific habitats, they cannot successfully complete their planktonic stage. Examples are intertidal barnacles which must be brought back to shore (Gaines \& Roughgarden 1987, Roughgarden et al. 1988) and reef fish larvae which must return to reef habitats (Cowen 1985, Victor 1986). For other species, however, habitat requirements during, or at the end of the planktonic stage, are not as strict. Planktonic offspring of some species are retained in 'retention areas' which increases survival, while transport away from these areas reduces survival (sensu lles \& Sinclair 1982).
Alternatively, for other species, survival is higher in 'nursery areas' which are separate from spawning areas, and failure of offspring to be transported to these favorable habitats results in lower survival (sensu Harden-Jones 1968). Using these types of arguments, it has been suggested that marine organisms reproduce at times which maximize the probability of offspring attaining the appropriate habitat, either during their planktonic stage (retention areas, some nursery areas) or at the end of their planktonic stage (adult habitats, other nursery areas). This implies that marine organisms are adapted to particular transport regimes and thus, deviations from these regimes could be a major factor in creating variable offspring survival and subsequently, variable recruitment (Parrish et al. 1981. Strathmann 1982\}.

This study examines the role of transport in regulating offspring survival in bluefish Pomatomus saltatrix (Pisces: Pomatomidae), a highly fecund marine fish species common in temperate and semi-tropical waters world-wide (Briggs 1960). Following planktonic egg 
and larval stages (Deuel et al. 1966. Norcross et al. 1974), bluefish juveniles enter estuarine nursery habitats (Hardy 1978, Kendall \& Walford 1979). Along the east coast of the United States, juveniles recruit to estuaries with a consistent intra-annual pattern: a springspawned cohort enters estuaries in late May to early June, and a summer-spawned cohort enters the same estuaries in July through October (Nyman \& Conover 1988, McBride \& Conover 1991, McBride et al. in press). It is currently believed that bluefish spawn in 2 distinct episodes and that the 2 juvenile cohorts simply reflect this spawning pattern (Kendall \& Walford 1979 , Chiarella \& Conover 1990).

In this paper we critically review the available evidence regarding bluefish spawning periodicity and conclude that, rather than occurring as 2 distinct events, spawning is in fact continuous and protracted. We then develop a simple transport model to address the question of whether transport processes can consistently create the appearance of 2 juvenile cohorts from a continuous production of offspring. We discuss the model's results in terms of particular transport mechanisms which may increase intra-and interannual recruitment variability. Finally, we consider the evolutionary implications of a reproductive strategy which produces offspring at times of predictably low offspring survival.

\section{REVIEW OF BLUEFISH LIFE HISTORY}

Bluefish is one of several finfish species which makes large-scale annual migrations along the eastern seaboard of the United States. During summer, bluefish are found from the Carolinas, north to the Gulf of Maine. They migrate south in the fall to their wintering

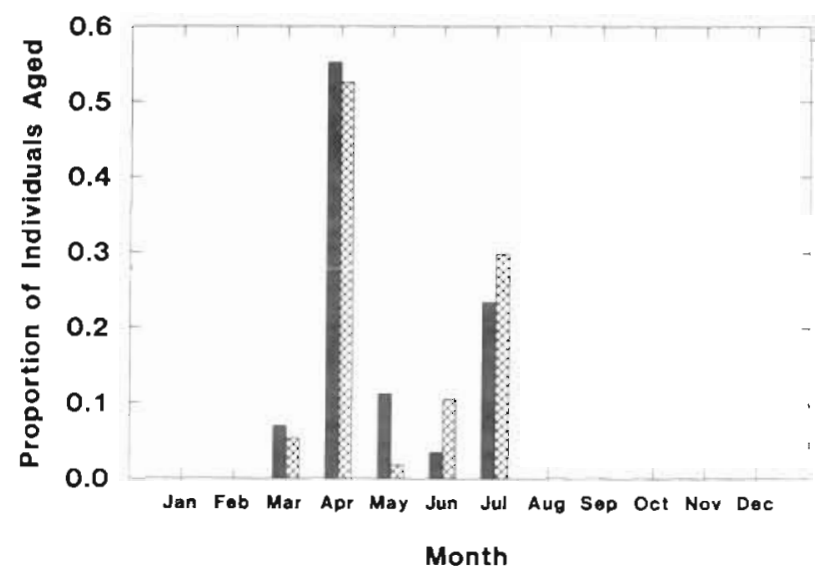

Fig. 1. Pomatomus saltatrix. Back-calculated birthdates of estuarine juvenile bluefish collected in Great South Bay, New York during 1987 ( $\mathrm{n}=116$, heavy hatched bars) and 1988 ( $\mathrm{n}=57$, light hatched bars). This figure is modified from McBride (1989) grounds off of Georgia and Florida. In the spring, bluefish move northwards along the coast, returning to their summer range (Bigelow \& Schroeder 1953, Wilk 1977).

As stated above, bluefish are currently believed to spawn in 2 distinct episodes: one in the spring in the South Atlantic Bight (SAB, Cape Canaveral, Florida to Cape Hatteras, North Carolina) and one in the summer in the Middle Atlantic Bight (MAB, Cape Hatteras to Cape Cod, Massachusetts). This hypothesis was first proposed by Kendall \& Walford (1979) based on ichthyoplankton surveys conducted along the east coast of the United States in the mid-1960s and early 1970s (see Clark et al. 1969, 1970 for details of the main body of sampling). This two-spawning hypothesis was consistent with evidence for different populations in the western Atlantic based on gill raker counts (Lund 1961) and scale morphology (Wilk 1977). Additional support for the two-spawning hypothesis was provided by Chiarella \& Conover (1990) who found that bluefish did not begin to reproduce off of New York until late June, even though adults were present in May and early June. Chiarella \& Conover (1990) also showed that their reproductive indices coincided with the presence of bluefish larvae in the New York Bight and they concluded that fish spawning off of New York in late June, July and early August were part of the second spawning event.

Along with the larval and reproductive evidence for the two-spawning hypothesis, several studies have shown that back-calculated birthdate distributions of estuarine juvenile bluefish consist of 2 back-calculated birthdate groups: a spring-spawned cohort with birthdates from mid-March to mid-May and a summerspawned cohort with birthdates from mid-June through July (Fig. 1). This pattern in juvenile birthdates has been found in collections made in Great South Bay, New York and the Hudson River Estuary during 1986 to 1988 (Nyman 1987, McBride \& Conover 1991) and in Mt. Hope Bay, Massachusetts, during 1991 (R. McBride pers. comm.). Earlier studies have also indicated 2 juvenile cohorts in Sandy Hook Bay, New Jersey, during the 1920s, bays around Long Island, New York, during the 1930s, Delaware Bay in the late 1950's and in Barneget Bay, New Jersey, during the 1970s (Nichols \& Breder 1926, de Sylva et al. 1962, and citations in McBride \& Conover 1991). These studies, carried out over the past 7 decades from Delaware to Massachusetts, indicate that the pattern of 2 juvenile cohorts is a general feature of bluefish recruitment in coastal areas of the Middle Atlantic Bight.

Generally, it has been concluded that the 2 cohorts of juvenile bluefish are evidence for 2 distinct spawning events. This conclusion implies that bluefish recruitment is directly coupled to offspring production. 
Survival of the early life history stages of other marine organisms, however, has been shown to be decoupled from reproduction (e.g. Methot 1983, Yoshioka 1986). Thus, the birthdates of juvenile bluefish may be a biased estimate of the timing of spawning, because juveniles represent only those individuals which have survived. At the outset of this study, we felt it necessary to reconsider the two-spawning hypothesis through an examination of data from a variety of sources, combining previously considered data with information which has been collected since the twospawning hypothesis was proposed. These data include gonosomatic indices (GSI) from different locations along the east coast, as well as larval abundances and distributions from the Marine Monitoring and Assessment Program, which sampled the continental shelf waters of the eastern United States. We predicted that if spawning occurs as 2 distinct episodes, both GSI and larval abundances should be temporally bimodal, and larval distributions should show 2 spatial-temporal groups.

\section{Gonosomatic indices}

Gonosomatic index data were obtained from 2 locations in the SAB (J. Finucane \& L. A. Collins pers. comm.) and from 1 location in the MAB (Chiarella \& Conover 1990). J. Finucane \& L. A. Collins (pers. comm.) examined 546 male and 296 female bluefish from southeastern Florida collected in all months except for August, October and November. They also examined 157 males and 224 females from the coast of the Carolinas collected from April to October. Chiarella \& Conover (1990) reported GSI based on 106 male and 127 female bluefish collected from June through September south of Long Island, New York. In both studies, gonads were treated similarly and GSI were calculated as the percent of gonad weight to total weight. Finucane \& Collins (pers. comm.), however, included both mature and immature fish in their calculations, making their monthly mean GSI more conservative than those of Chiarella \& Conover (1990), whose calculations included only mature fish. The absolute value of GSI between these 2 studies, therefore, were not directly comparable, but the patterns in mean monthly GSI represented a measure of the reproductive seasonality of bluefish within each of the 3 areas.

Examination of both male and female GSI from the 3 geographic locations indicated that reproduction shifted gradually from early spring in Florida to summer in New York. Male GSI were relatively high in March and April in Florida, June and July in the Carolinas, and July and August in New York (Fig. 2). Female GSI exhibited a similar pattern with relative maximums in March and April in Florida, May and June in the Carolinas, and July and August in New York (Fig. 3). Both male and female GSI increased in the fall off of Florida, suggesting a shift in spawning back into the SAB coincidental with the fall southward migration. Although these collections do not cover a full year and are from only 3 locations along the coast, there is no indication of 2 distinct periods of high GSI values.

There are problems with using GSI as indicators of reproductive activity. DeVlaming et al. (1982) pointed out 4 assumptions inherent in the use of GSI. Unfortunately, these assumptions have not been con-
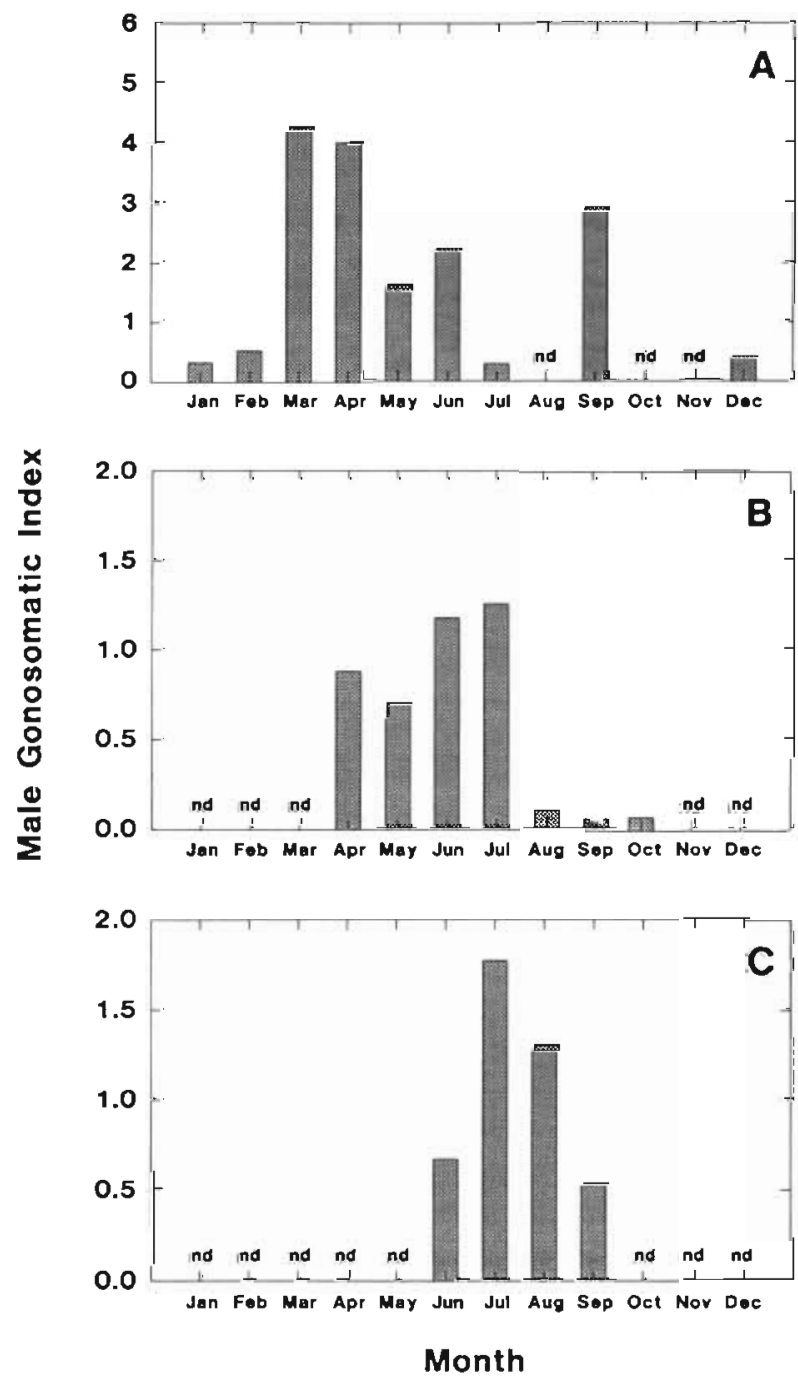

Fig. 2. Pomatomus saltatrix. Average monthly gonosomatic indices (gonad weight / total weight $\times 100$ ) for male bluefish from (A) southeastern Florida, (B) the Carolinas and (C) New York. Florida and Carolina data were collected by J. Finucane \& L. A. Collins (pers. comm.) and New York data was reported by Chiarella \& Conover (1990). nd: months from which no bluefish were examined 


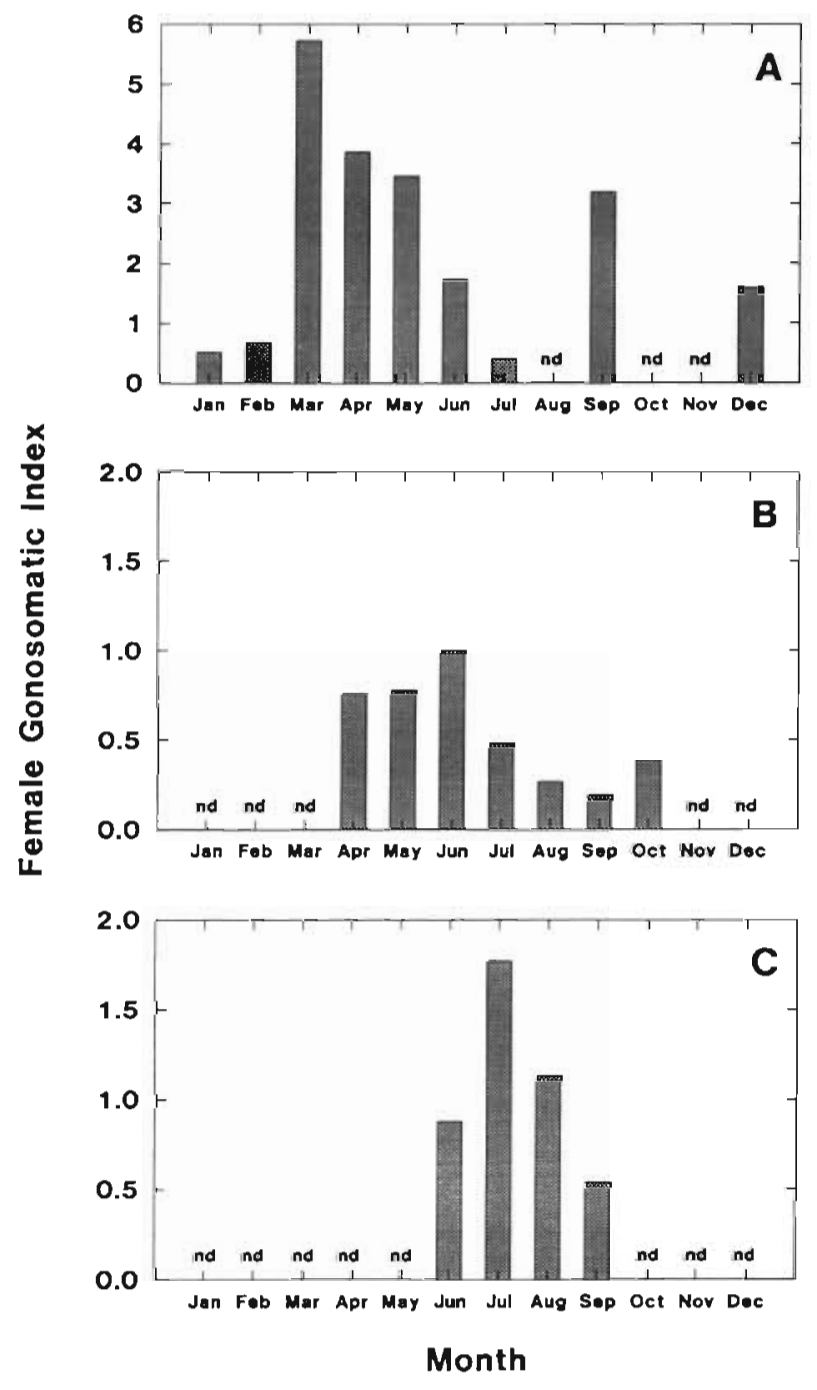

Fig. 3. Pomatomus saltatrix. Average monthly gonosomatic indices (gonad weight / total weight $\times 100$ ) for female bluefish from southeastern Florida (A), the Carolinas (B) and New York (C). Florida and Carolina data were collected by $J$ Finucane \& L. A. Collins (pers. comm.) and New York data was reported by Chiarella \& Conover (1990). nd: months from which no bluefish were examined

sidered with regards to bluefish. In addition, GSI give no indication of actual spawning. Therefore, we present these data recognizing their limitations, but maintain that examination of all available GSI data gives no indication of 2 distinct reproductive events.

\section{Larval abundance and distribution}

Bluefish larval. abundance and distribution data were obtained from 2 large-scale ichthyoplankton programs. Data for the MAB were obtained from the Marine Monitoring and Assessment Program (MAR-
MAP) of the Northeast Fisheries Center which sampled an area from Cape Hatteras, North Carolina to Cape Sable, Nova Scotia from 1977 to 1987 (Sibunka \& Silverman 1984, 1989, Morse et al. 1987, T. Potthoff pers. comm.). Ichthyoplankton samples were collected using a $61 \mathrm{~cm}$ bongo net with $505 \mu \mathrm{m}$ mesh towed in a double-oblique pattern to within a few meters of the bottom, or to a maximum depth of $200 \mathrm{~m}$ (see Sibunka \& Silverman 1984, 1989 for details of sampling). Similar data were used from the MARMAP surveys conducted from Cape Hatteras to Cape Canaveral, Florida from 1973 to 1980 by the South Carolina Marine Resources Research Institute (Powles \& Stender 1976, Collins \& Stender 1987). Most sampling was conducted using the same gear and methods as the MARMAP surveys north of Cape Hatteras. These SAB collections, however, were limited both in terms of collection effort and seasonal coverage, with no collections made in June or December. As a matter of comparison, from Cape Hatteras to Cape Canaveral, MARMAP occupied 1163 stations with a bongo net, while from Cape Hatteras to Cape Cod, 5389 stations were sampled with a bongo net. Bluefish larval abundance from these 2 sampling programs was examined in terms of mean monthly abundances (no. of larvae under $10 \mathrm{~m}^{2}$ of sea surface) of all size classes collected in the bongo net.

Mean monthly larval abundances indicated that bluefish larvae were present off the east coast from spring into fall (Fig. 4). In March and April larvae were

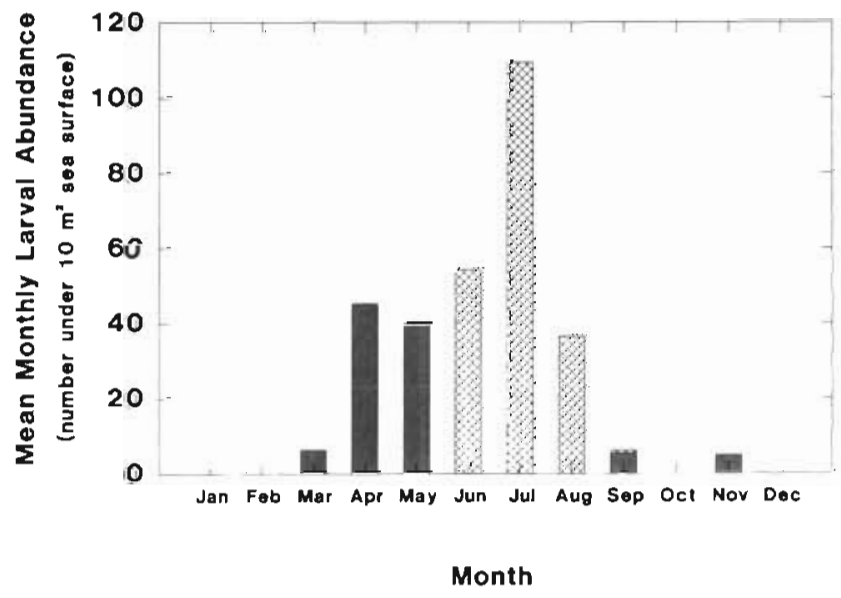

Fig. 4. Pomatomus saltatrix. Mean monthly abundance of bluefish larvae (no. of larvae under $10 \mathrm{~m}^{2}$ of sea surface) collected from the South Atlantic Bight (heavy hatched bars) and Middle Atlantic Bight (light hatched bars). South Atlantic Bight data are from collections made by the South Carolina Marine Resources Research Institute (Collins \& Stender 1987). These surveys did not conduct ichthyoplankton collections in June or December. Data from the Middle Atlantic Bight came from the year-round MARMAP surveys conducted by the Northeast Fisheries Center (T. Potthoff pers. comm.). See text for brief description of the sampling programs 

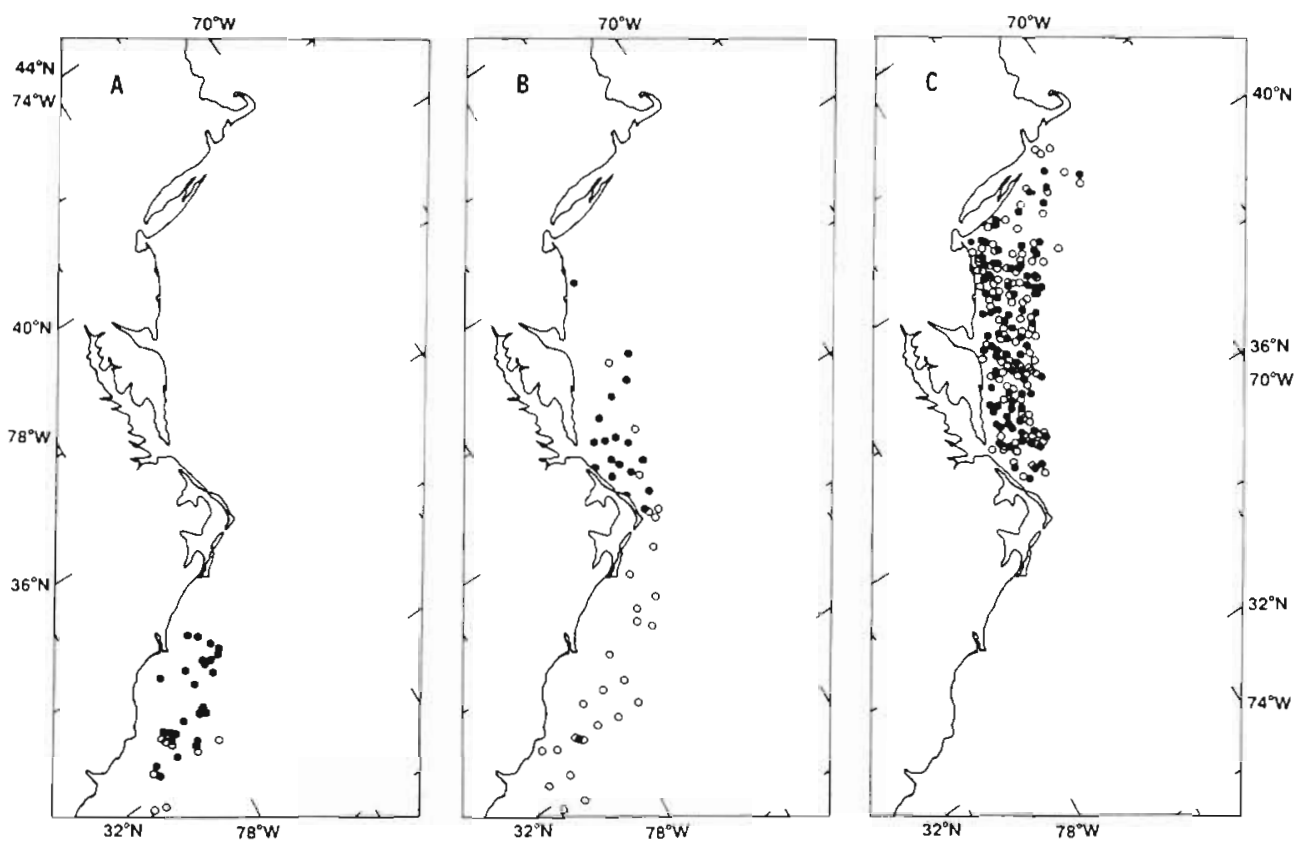

Fig. 5. Pomatomus saltatrix. Collections of bluefish larvae in the South and Middle Atlantic Bights by month: (A) March, $\bullet$ April; (B) : May; : June; (C) : July, •: August. Capture locations for SAB came from collections provided to us by Bruce Stender (South Carolina Marine Resources Research Institute). Data for the MAB were taken from the 1977 to 1984 MARMAP survey atlas (Morse et al. 1987). Coastline shown from Massachusetts to Georgia. See text for brief description of the sampling programs

collected only in the SAB. In May, larvae occurred both in the $\mathrm{SAB}$ and $\mathrm{MAB}$, but MAB abundances were low $\left(<1\right.$ larva under $\left.10 \mathrm{~m}^{2}\right)$. In June and July, larvae were found only in the $M A B$, but no collections were made in the $S A B$ in June. In August and into the fall, there was a decrease in larval abundance and a shift back to the $S A B$ from the MAB. These data exhibited a partial spatial separation of larvae between the $S A B$ and $M A B$, with limited overlap in May and unfortunately, no data from the $\mathrm{SAB}$ in June. Larval abundances, however, provide no indication of a temporal break in spawning consistent with the May to June gap seen in back-calculated birthdate distributions of estuarine juveniles (Fig. 1).

Monthly distributions of bluefish larvae progressed northwards from the southern $\mathrm{SAB}$ in the early spring to the northern MAB in the summer (Fig. 5). In March and April, larvae were collected only in the SAB, south of 33 and $34^{\circ} \mathrm{N}$ respectively (Fig 5A). Larvae were found throughout the $\mathrm{SAB}$ and into the southern $\mathrm{MAB}$ in May (Fig. 5B). In July and August, larvae were restricted to the $M A B$ with the northern limit shifting northwards between June and July (Fig. 5B and 5C). In September, very few larvae were caught in the $M A B$ and $\mathrm{SAB}$, and in October and November they were limited to the SAB (Fig. 4; Collins \& Stender 1987). These distribution data give no indication that spawning occurs as 2 distinct spatial events.

\section{An alternative view of bluefish life history}

From this review of gonosomatic indices, larval abundances and larval distributions, we find little evidence to support the two-spawning hypothesis. It appears that spawning begins in March in the southern reaches of the $\mathrm{SAB}$, evidenced by the high March GSI in Florida (Figs. $2 \& 3$ ) and low larval abundances restricted to the southern portions of the SAB (Figs. $4 \&$ $5 \mathrm{~A})$. As spring progresses, GSI decline in Florida and begin to increase in the Carolinas (Figs. 2 \& 3); larvae are found in greater abundances and progressively further north, and in May, larvae are found north of Cape Hatteras (Figs. $4 \& 5 \mathrm{~A}, \mathrm{~B}$ ). In June, larval abundances increase in the $\mathrm{MAB}$ coinciding with the rising GSI (Figs. 2, $3 \& 4$ ). GSI are still high in the SAB in June, but unfortunately no larval collections are available (Figs. 2 \& 3). Larvae are restricted to the MAB during July and August, while MAB GSI peak in July, then begin to decrease (Figs. 2, 3, 4 \& 5C). In the fall, there is a shift of larvae back to the SAB with a corresponding increase in GSI in the Carolinas and Florida (Figs. 2, $3 \& 4$ ). Based on these data, we propose an alternative hypothesis regarding bluefish reproduction: spawning occurs continuously and over a protracted period, beginning with the northward migration in the spring, continuing throughout the summer and dropping off in the fall with the southward migration. 
Our alternative hypothesis of bluefish life history is consistent with other work which has focused on various aspects of bluefish biology. In very limited ichthyoplankton sampling off of Chesapeake Bay, Norcross et al. (1974) found that both bluefish larval numbers and lengths increased from May through July, supporting the idea that spawning continues into the southern MAB from the northern SAB in May and June. Van der Elst (1976) concluded that individual bluefish spawn repeatedly over a period of 5 to 6 mo along the east coast of South Africa, which is consistent with our hypothesis of continual spawning along the east coast of the United States. In addition, Chiarella \& Conover (1990) found bluefish which were spawned in the spring reproducing in the summer, suggesting that spring- and summer-spawned fish are not reproductively isolated.

From the data reviewed here, we cannot reject the two-spawning hypothesis. However, we find no evidence of 2 distinct spawning events and believe the data support the hypothesis that spawning occurs continuously from March to at least September. Unfortunately our analysis is limited to a population level description and there are important individual level questions which need to be addressed before the twospawning hypothesis, or for that matter our continuous-spawning hypothesis, can be rejected. Do individuals spawn serially and if so, how many times in a year? What is the pattern of individual reproduction and migration? Is there any age, size or population structure to spawning? Knowledge regarding the spatial and temporal distribution of bluefish eggs along the east coast of the United States would also aid in distinguishing between the 2 hypotheses, as would data on the distribution of larvae in the SAB in June. Another problem which must be addressed, if our continuous spawning hypothesis is correct, is identifying the mechanism which consistently creates the appearance of 2 juvenile cohorts from one continuous spawning. The remainder of this paper will examine one such mechanism.

\section{DEVELOPMENT OF TRANSPORT MODEL}

There is debate regarding the processes which drive survival of the early life history stages of marine fish (see reviews by Rothschild 1986, Sinclair 1988). In some species biological processes are clearly important (e.g. Lasker 1975, 1978), but strict biological scales, such as the scale of feeding or predation, are smaller than the scale implied by the temporal persistence of bluefish recruitment pattern (see discussion by Rothschild 1986). A bimodal pattern of survivorship has been documented for juvenile bluefish in various estuaries throughout the MAB. The temporal persistence of this pattern, observed as early as the 1920s, and the spatial scale of bluefish reproduction and recruitment suggest that the processes responsible operate on temporal scales of tens of years and on spatial scales of hundreds to thousands of kilometers. These dimensions are characteristic of large-scale oceanographic features such as ocean currents and large oceanic eddies (Stommel 1963, Haury et al. 1978). Thus, as a first order examination of bluefish survival and recruitment, we constructed a simple transport model which incorporated components of the largescale circulation of the region. To develop our transport model, the estuarine recruitment patterns of juvenile bluefish must be described further and the large-scale physical oceanography of the region must also be reviewed.

Bluefish juveniles are believed to be estuarine dependent (Hardy 1978, Kendall \& Walford 1979) and enter MAB estuaries at about 2 mo of age (McBride 1989). Relative abundance of the 2 juvenile cohorts in estuaries is variable and McBride \& Conover (1991) have suggested that the spring-spawned cohort is more consistent between years than the summerspawned cohort. Spring-spawned fish recruit primarily to $M A B$ estuaries, although small numbers do recruit to $\mathrm{SAB}$ estuaries (McBride et al. in press). Summerspawned fish recruit primarily to $\mathrm{MAB}$ estuaries, but some have been collected in SAB estuaries in early fall. It is not known, however, if these summer-spawned fish are actually recruiting to SAB estuaries or entering them as part of their fall migration after previously entering estuaries in the MAB (McBride et al. in press).

The large-scale physical oceanography of the region consists of 3 basic components. The first component is the Gulf Stream, which flows north-northeast along the edge of the continental shelf south of Cape Hatteras at ca 100 to $200 \mathrm{~cm} \mathrm{~s}^{-1}$ (Pierce \& Joyce 1988. Joyce et al. 1990). North of Cape Hatteras, the shelf edge turns north and the Gulf Stream continues flowing northeastward into the Slope Sea (Brown et al. 1986), the region between the Gulf Stream and the continental shelf from Cape Hatteras to the Grand Banks (Csanady \& Hamilton 1988). The second component is southwestward-flowing $M A B$ shelf water and Slope Sea water with average speeds between 5 and $10 \mathrm{~cm} \mathrm{~s}^{-1}$ (Beardsley et al. 1976, Csanady \& Hamilton 1988, Pierce \& Joyce 1988). These flows are incorporated into the northeastward-flowing Gulf Stream in the region between the eastern shore of Virginia and Cape Hatteras (Ford et al. 1952, Fisher 1972, Churchill et al. 1989, Lillibridge et al. 1990). A third component consists of exchange from the Gulf Stream back to the $\mathrm{MAB}$ shelf edge through the formation of warm-core ring streamers; these are ribbons of Gulf Stream water 


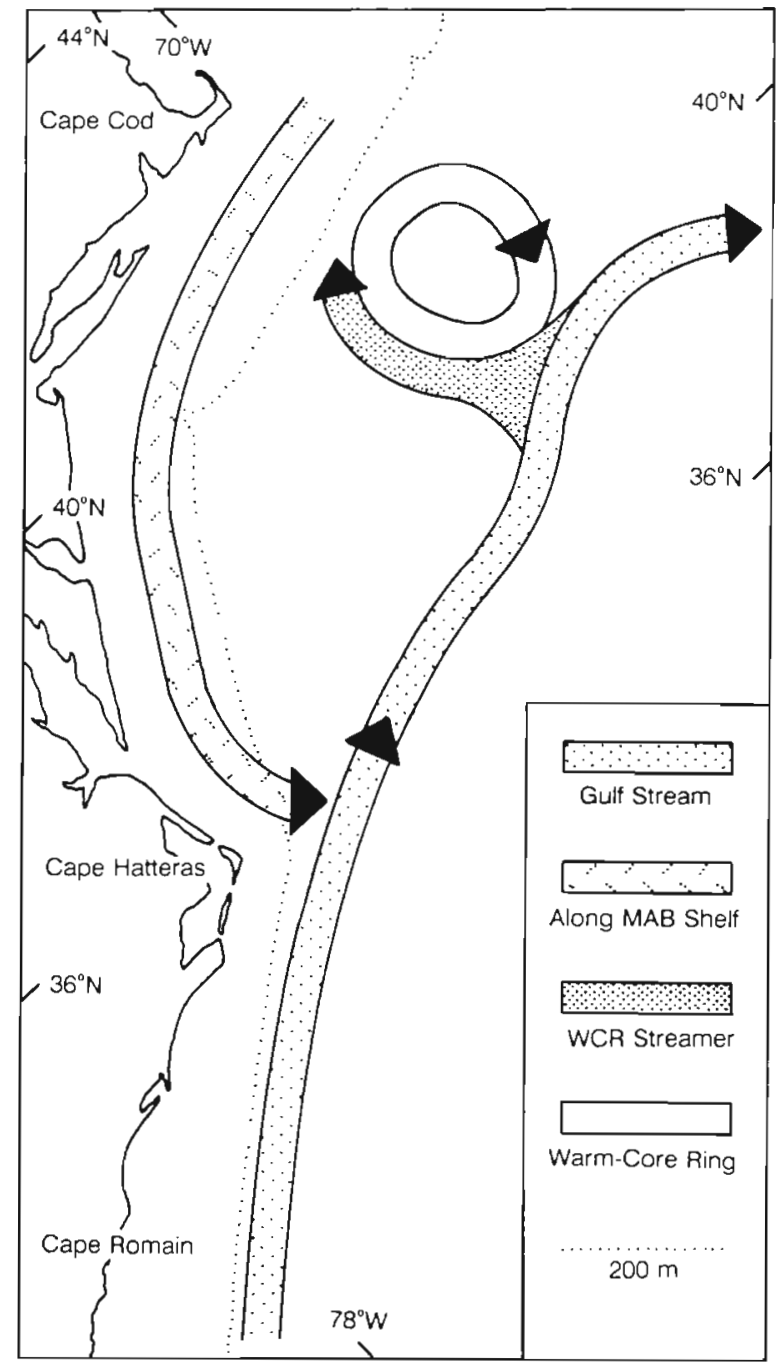

Fig. 6. Basic advective components of the large-scale circulation along the east coast of the United States

which are rapidly carried around the western side of warm-core rings and which deposit Gulf Stream water at the MAB shelf break (Hare \& Cowen 1991, J. H. Churchill et al. unpubl.) (see Fig. 6 for a schematic of the large-scale circulation).

Based on our alternative hypothesis of bluefish reproduction and the large-scale circulation of the region, the model assumed that spawning occurs continuously during the northward migration and that transport of offspring occurs in 3 components: the Gulf Stream, the along-shelf current of the MAB, and across the Slope Sea from the Gulf Stream to the MAB shelf. In our model, offspring spawned south of Cape Hatteras were transported northeastward in the Gulf Stream and then across the slope to the MAB shelf. If they reached the MAB shelf before the age of recruitment, it was assumed that they could recruit to an

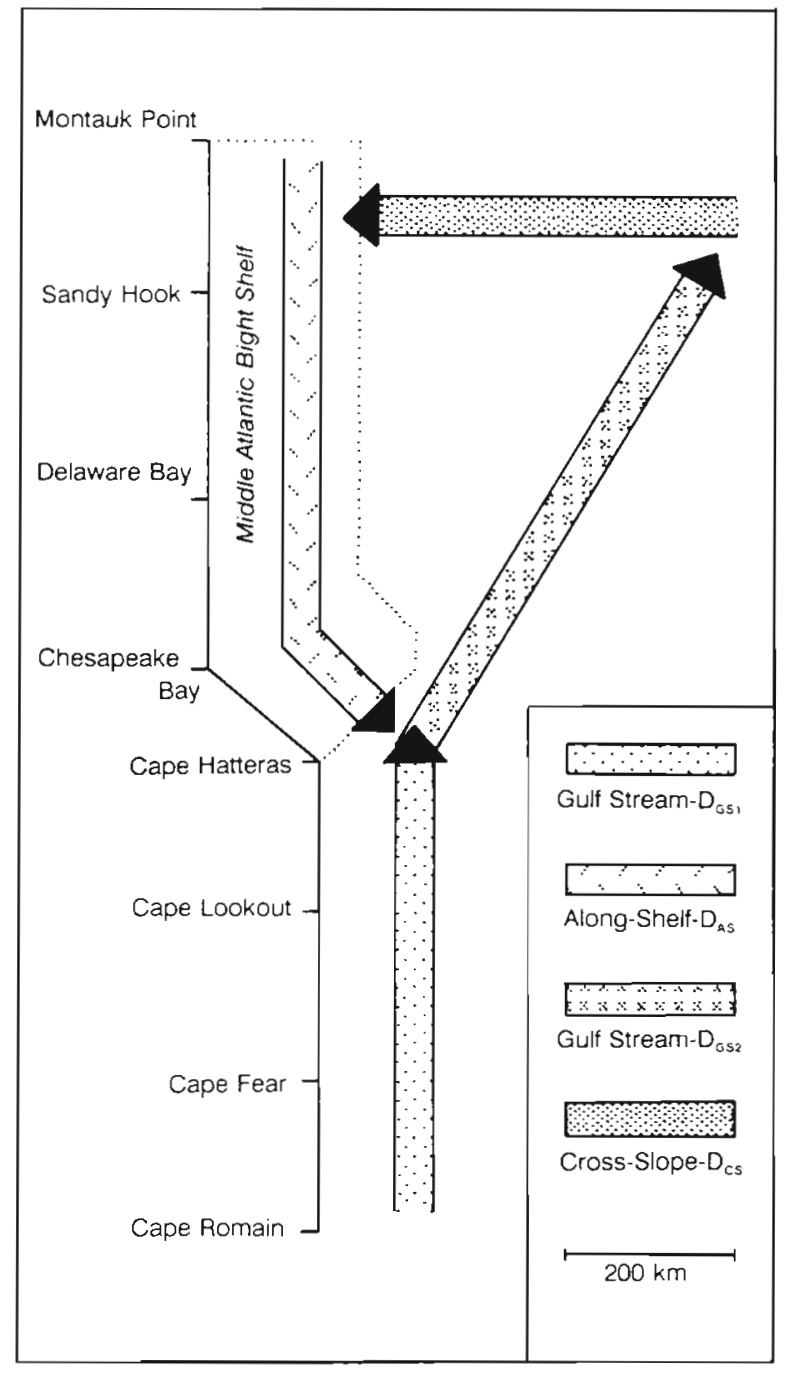

Fig. 7. Schematic of the larval transport model showing the 3 transport components considered

estuary. Alternatively, offspring spawned north of Cape Hatteras were carried southwestward along the MAB shelf to Cape Hatteras, at which point they were incorporated into the Gulf Stream, carried northeastward, and then across the slope back to the MAB shelf. If these MAB-spawned offspring were not transported off the shelf or were transported off but then back to the shelf via the cross-slope mechanism before the age of recruitment, it was assumed that they could recruit to an estuary. Thus, the model determined if offspring spawned at a particular spawning location would either make it to, or not leave, the MAB shelf in the time before estuarine recruitment (see Fig. 7 for a schematic of the model).

Specifically, the transport model was made up of a series of distance-speed equations which calculated the amount of time needed for offspring spawned at a 
particular location to be transported over a particular component, either the Gulf Stream, along-shelf or cross-slope. These times could then be used to determine if offspring from a given spawning location would end up on the MAB shelf within a certain period of time, termed the 'survival age', which represents the age at which recruitment to the estuaries occurs. The equations used in the model are as follows:

$$
\begin{aligned}
& T_{\mathrm{CH}}=V_{\mathrm{GS}} D_{\mathrm{CS} 1}+V_{\mathrm{AS}} D_{\mathrm{AS}} \\
& T_{\mathrm{GS} 2}=V_{\mathrm{GS}} D_{\mathrm{CS} 2} \\
& T_{\mathrm{CS}}=V_{\mathrm{CS}} D_{\mathrm{CS}}
\end{aligned}
$$

where $T_{\mathrm{CH}}=$ time required for transport from a spawning location to Cape Hatteras; $T_{\mathrm{GS} 2}=$ time required for transport from Cape Hatteras to the cross-slope component; $T_{\mathrm{CS}}=$ time required to cross the slope from the Gulf Stream to the MAB shelf; $V_{\mathrm{GS}}=$ transport speed of the Gulf Stream component; $V_{\text {AS }}=$ transport speed of the along-shelf component; $V_{C S}=$ transport speed of the cross-slope component $D_{\mathrm{GS} 1}=$ distance from $\mathrm{SAB}$ spawning locations to Cape Hatteras; $D_{\mathrm{AS}}=$ distance from MAB spawning locations to Cape Hatteras; $D_{\mathrm{CS} 2}=$ distance from Cape Hatteras to the cross-slope component; and $D_{\mathrm{CS}}=$ distance cross-slope from the Gulf Stream to the MAB shelf.

There were 4 basic conditions of the model. First, bluefish spawning was resolved into 29 spawning locations representing a range from Cape Romain, South Carolina to Montauk Point, New York. Spawning locations in the SAB (south of Cape Hatteras) had $D_{\mathrm{AS}}$ equal to zero and values of $D_{\mathrm{GS} 1}$ which increased from Cape Hatteras to Cape Romain. Spawning locations in the MAB (north of Cape Hatteras) had $D_{\mathrm{GS} 1}$ equal to zero and values of $D_{\text {AS }}$ increasing from Cape Hatteras to Montauk Point (Table 1).

The second condition defined the transport speeds of the various components. For each component, 3 transport speeds were used which represented a range of possible speeds obtained from the literature. Gulf Stream transport speeds ranged from $50 \mathrm{~cm} \mathrm{~s}^{-1}$ to $100 \mathrm{~cm} \mathrm{~s}^{-1}$, the speed of water moving northeastward in association with the Gulf Stream and the approximate speed of the Gulf Stream at the north wall, respectively (Pierce \& Joyce 1988, Joyce et al. 1990, Lillibridge et al. 1990). Along-shelf transport speeds ranged from $2.5 \mathrm{~cm} \mathrm{~s}^{-1}$, a low to average shelf current, to $7.5 \mathrm{~cm} \mathrm{~s}^{-1}$, an average to moderately high shelf flow (Scott \& Csanady 1976, Beardsley et al. 1985, Flagg et al. in press). Cross-slope transport speeds were chosen to represent 2 possible crossing mechanisms, either active swimming by individuals (Shima 1989, Cowen \& Hare unpubl. data) or transport associated with warmcore ring streamers (Hare \& Cowen 1991); $10 \mathrm{~cm} \mathrm{~s}^{-1}$ represented an approximate swimming speed (e.g. a
Table 1 Values of spawning block locations used in the transport model where 0 represents Cape Hatteras, negative values represent locations south of Cape Hatteras and positive values represent locations north of Cape Hatteras. Also given are the $D_{\mathrm{GS}}$ and $D_{\mathrm{AS}}$ values (distance to Cape Hatteras from $\mathrm{SAB}$ and $\mathrm{MAB}$ spawning locations, respectively for each

\begin{tabular}{|c|c|c|}
\hline Spawning block location & $D_{\mathrm{GS} 1}$ & $D_{\text {AS }}$ \\
\hline-432 & 432 & 0 \\
\hline-396 & 396 & 0 \\
\hline-360 & 360 & 0 \\
\hline-324 & 324 & 0 \\
\hline-288 & 288 & 0 \\
\hline-252 & 252 & 0 \\
\hline-216 & 216 & 0 \\
\hline-180 & 180 & 0 \\
\hline-144 & 144 & 0 \\
\hline-108 & 108 & 0 \\
\hline-72 & 72 & 0 \\
\hline-36 & 36 & 0 \\
\hline 0 & 0 & 0 \\
\hline 36 & 0 & 36 \\
\hline 72 & 0 & 72 \\
\hline 108 & 0 & 108 \\
\hline 144 & 0 & 144 \\
\hline 180 & 0 & 180 \\
\hline 216 & 0 & 216 \\
\hline 252 & 0 & 252 \\
\hline 288 & 0 & 288 \\
\hline 324 & 0 & 324 \\
\hline 360 & 0 & 360 \\
\hline 396 & 0 & 396 \\
\hline 432 & 0 & 432 \\
\hline 468 & 0 & 468 \\
\hline 504 & 0 & 504 \\
\hline 540 & 0 & 540 \\
\hline 576 & 0 & 576 \\
\hline
\end{tabular}
spawning block location which were used in the calculation of the model. All values are in kilometers. See text for details

$5 \mathrm{~cm}$ fish swimming 2 body lengths $\mathrm{s}^{-1}$; Hunter 1981), and $50 \mathrm{~cm} \mathrm{~s}^{-1}$ represented the higher end of warmcore ring streamer velocities (Churchill et al. unpubl.) (see Table 2 for list of values used).

The third condition was that estuarine recruitment was determined at a particular 'survival age' (SA). If offspring from a given spawning location were on the MAB shelf at a given 'survival age', they were assumed to be able to recruit to an estuary. Alternatively, if offspring from a spawning location were not on the MAB shelf at a given 'survival age', they were assumed not to be able to recruit. Three 'survival ages' were used which covered the range of 
ages at estuarine recruitment as reported by McBride (1989) (Table 2).

The fourth condition was that the location of the cross-slope component was not constant. If individuals were swimming across the slope, their location at the initiation of behavior would be variable. Likewise, the location of warm-core ring streamers is also variable (Hare \& Cowen 1991, Cowen et al. in press). Therefore, we used 4 values of $D_{\mathrm{GS} 2}$, the distance from Cape Hatteras to the cross-slope mechanism, to incorporate the variable location of this mechanism. The values used ranged from 336 to $660 \mathrm{~km}$, locations perpendicular to Delaware Bay and Narragansett Bay, respectively (Table 2).

From the equations and the 4 conditions, 'survival' of offspring from a particular spawning location could occur in one of two ways. First, for offspring spawned in the $\mathrm{MAB}\left(D_{\mathrm{AS}}>0\right)$, if $V_{\mathrm{AS}} D_{\mathrm{AS}}>S A$ (criteria 1), then offspring remained on the $M A B$ shelf and 'survived' to recruit. Second, for both MAB-and SAB-spawned offspring, if $T_{\mathrm{CH}}+T_{\mathrm{GS} 2}+T_{\mathrm{CS}} \leq S A$ (criteria 2), then offspring reached the $\mathrm{MAB}$ shelf via the cross-slope mechanism before the specified 'survival age' and were able to recruit to an estuary.

The model was run using 3 sets of variables. First, the 2 'survival' criteria were determined for all spawning locations ( $n=29$ ) using each possible combination of transport speeds $(n=27)$, with $S A$ set at $60 \mathrm{~d}$ (the average age at estuarine recruitment) and $D_{\mathrm{GS} 2}$ set at $444 \mathrm{~km}$ (cross-slope location perpendicular to Sandy Hook, New Jersey). Second, all spawning locations (n $=29$ ) were used with all 'survival ages' $(n=3)$ and all combinations of transport speeds $(n=27)$, with $D_{\mathrm{GS} 2}$ set at $444 \mathrm{~km}$. Third, the model was run using all spawning locations $(n=29)$, all cross-slope locations $(n=4)$ and all combinations of transport speed ( $\mathrm{n}=27$ ), with $S A$ set at $60 \mathrm{~d}$.

Table 2. Transport speeds, 'survival ages' and locations of the cross-slope component which were used in the transport model. Transport speeds are given for each of the 3 transport components: along-shelf ( $\left.V_{\mathrm{AS}}\right)$, Gulf Stream ( $\left.V_{\mathrm{GS}}\right)$ and crossslope $\left(V_{C S}\right)$, and are in $\mathrm{cm} \mathrm{s}^{-1}$ 'Survival ages' $(S A)$ are in days and cross-slope locations $\left(D_{\mathrm{CS}_{2}}\right)$ are in $\mathrm{km}$. In the first run of the model all 27 speed values were used with $S A=60$ and $D_{\mathrm{GS} 2}=444$. The second run used all speed values and all $S A$ values with $D_{\mathrm{GS} 2}=444$. In the third model run all speed values were used with all $D_{\mathrm{GS} 2}$ values and $S A=60$. See text for details

\begin{tabular}{|rrrrr|}
\hline$V_{\mathrm{AS}}$ & $V_{\mathrm{GS}}$ & $V_{\mathrm{CS}}$ & $S A$ & $D_{\mathrm{GS} 2}$ \\
\hline 2.5 & 50 & 10 & 40 & 336 \\
5.0 & 75 & 25 & 60 & 444 \\
7.5 & 100 & 50 & 80 & 552 \\
& & & & 660 \\
\hline
\end{tabular}

To examine the results of the model, we assumed a link between 'survival' as determined by our model and the probability of estuarine recruitment. If offspring from a particular spawning location ended up on the MAB shelf under all transport speed combinations, it was concluded that their transport to the MAB shelf was independent of transport speed and that they would have a high probability of estuarine recruitment. Likewise, if offspring from a given spawning location made it to the MAB shelf only under a limited number of transport speed combinations, it was concluded that their transport to the shelf was dependent on a restricted set of current speeds and that they would have a lower probability of estuarine recruitment. Thus, the number of transport speed combinations of the 3 transport components which resulted in 'survival' for a particular spawning location was considered a measure of the relative probability of estuarine recruitment for that spawning location. As a measure of recruitment probability, however, the number of combinations resulting in survival cannot be considered to be a linear; it is a relative measure.

\section{RESUITS OF TRANSPORT MODEL}

To examine the effect of the speed of individual transport components on recruitment probability, results of the first model run were visualized 3-dimensionally: spawning location, speed of particular transport component and combinations of transport speeds of the other 2 components which resulted in 'survival' (maximum $=9$ ). For the along-shelf component, the model predicts that individuals spawned in the southern MAB have a lower recruitment probability relative to those individuals spawned in the $S A B$ and northern MAB (Fig. 8A). The model also suggests that as alongshelf transport speed increases, the geographic area which produces lower recruitment shifts northward and the trough of low recruitment probability deepens. In a similar examination of the Gulf Stream component, the model predicts that the bimodal pattern is largely independent of Gulf Stream transport speed, except for a slight decrease in recruitment probability of offspring spawned in the southern MAB at speeds $\leq 60 \mathrm{~cm} \mathrm{~s}^{-1}$ (Fig. 8B). Analysis of the third component, cross-slope transport, indicates that recruitment probability from the southern portion of the MAB decreases with decreasing cross-slope transport speeds, but at all speeds the pattern of lower recruitment from the southern MAB is evident (Fig. 8C). Thus, the model indicates that low recruitment probability in the southern portion of the MAB is dependent on along-shelf transport speeds, slow cross-slope 

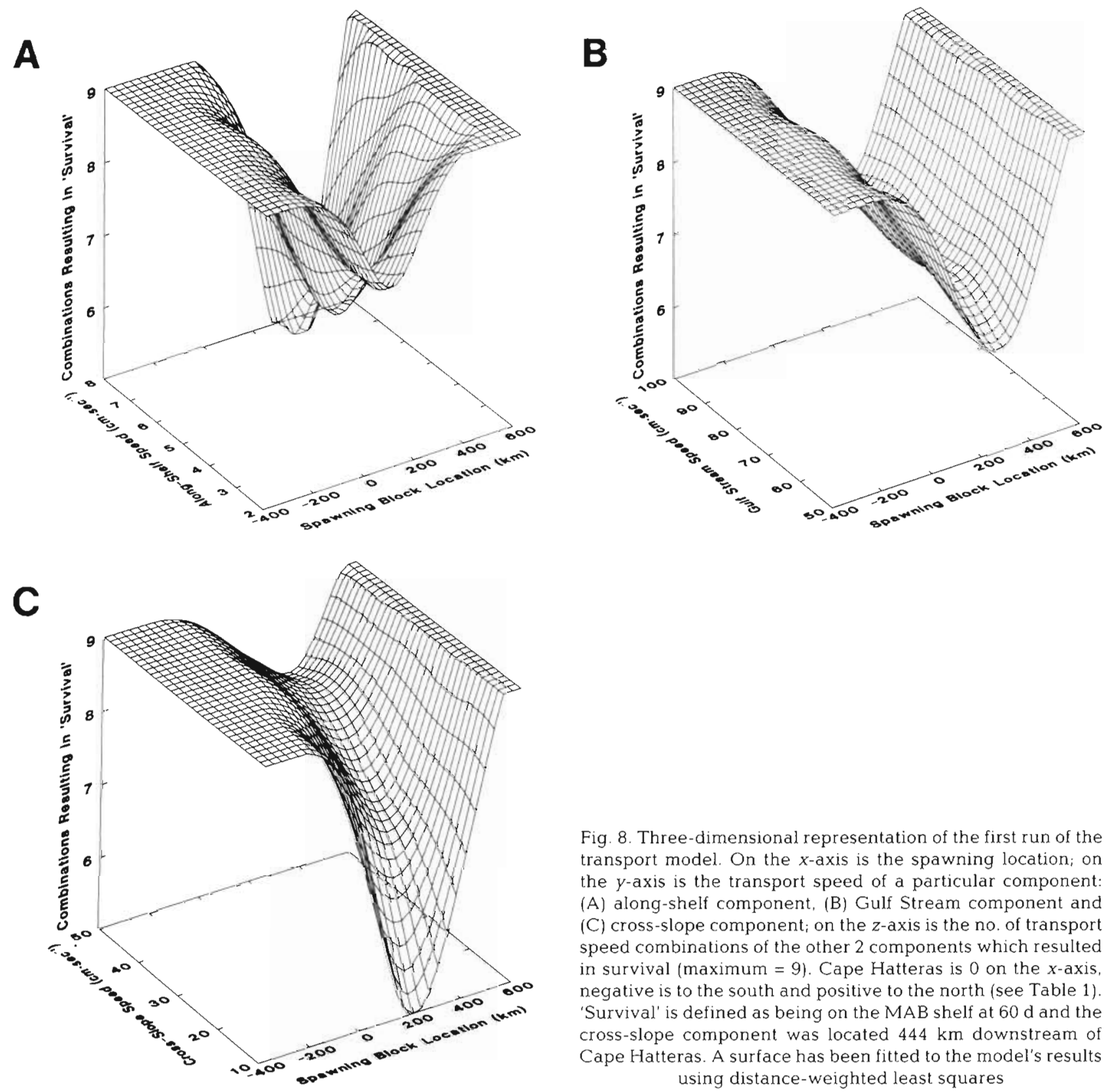

Fig. 8. Three-dimensional representation of the first run of the transport model. On the $x$-axis is the spawning location; on the $y$-axis is the transport speed of a particular component (A) along-shelf component, (B) Gulf Stream component and (C) cross-slope component; on the $z$-axis is the no. of transport speed combinations of the other 2 components which resulted in survival (maximum $=9$ ). Cape Hatteras is 0 on the $x$-axis, negative is to the south and positive to the north (see Table 1). 'Survival' is defined as being on the MAB shelf at $60 \mathrm{~d}$ and the cross-slope component was located $444 \mathrm{~km}$ downstream of Cape Hatteras. A surface has been fitted to the model's results using distance-weighted least squares

speeds and, to a lesser extent, slow Gulf Stream transport speeds.

The second run of the model examined the effects which 'survival age' has on recruitment probability. For young recruitment ages (40 to $50 \mathrm{~d}$ ), the model predicts a decrease in recruitment probability of those individuals spawned in both the southern portions of the $\mathrm{SAB}$ and $\mathrm{MAB}$, however, the bimodal pattern is still apparent (Fig. 9A). At older ages (70 to $80 \mathrm{~d}$ ), the pattern was very similar to that found in the first model run using $60 \mathrm{~d}$, but the decrease in recruitment probability shifted to the north. Thus, recruitment age affects the position of the area of lowest recruitment probability but does not affect the overall pattern of bimodality.

With the third run of the model, we examined the effect of the location of the cross-slope component. The model predicts that location of the cross-slope component has little effect on pattern of recruitment (Fig. 9B). This result is expected because increasing $D_{G S 2}$, the distance from Cape Hatteras to the crossslope component, is analogous to decreasing $V_{\mathrm{GS}}$ which has already been shown to have little effect (Fig. 8B) 
A

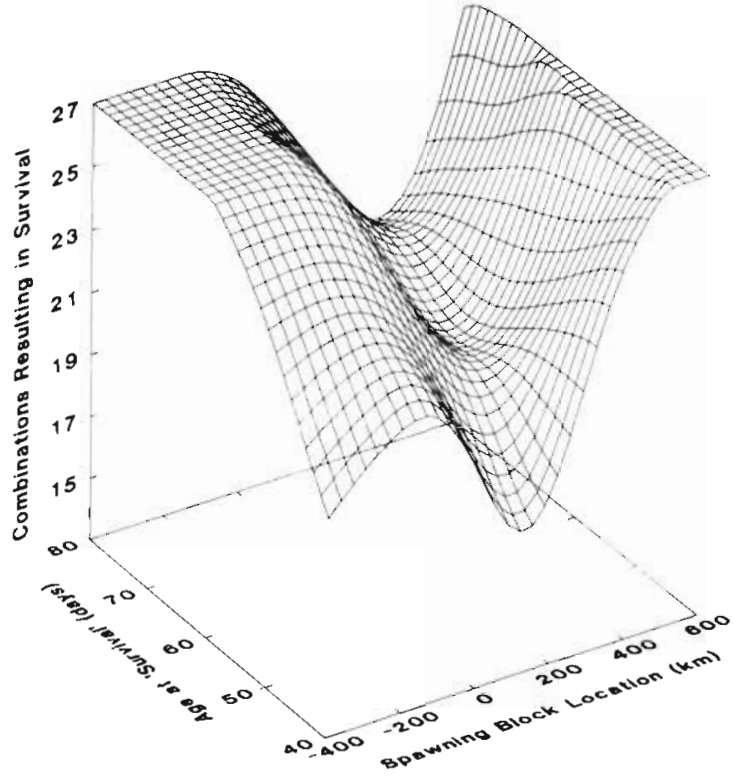

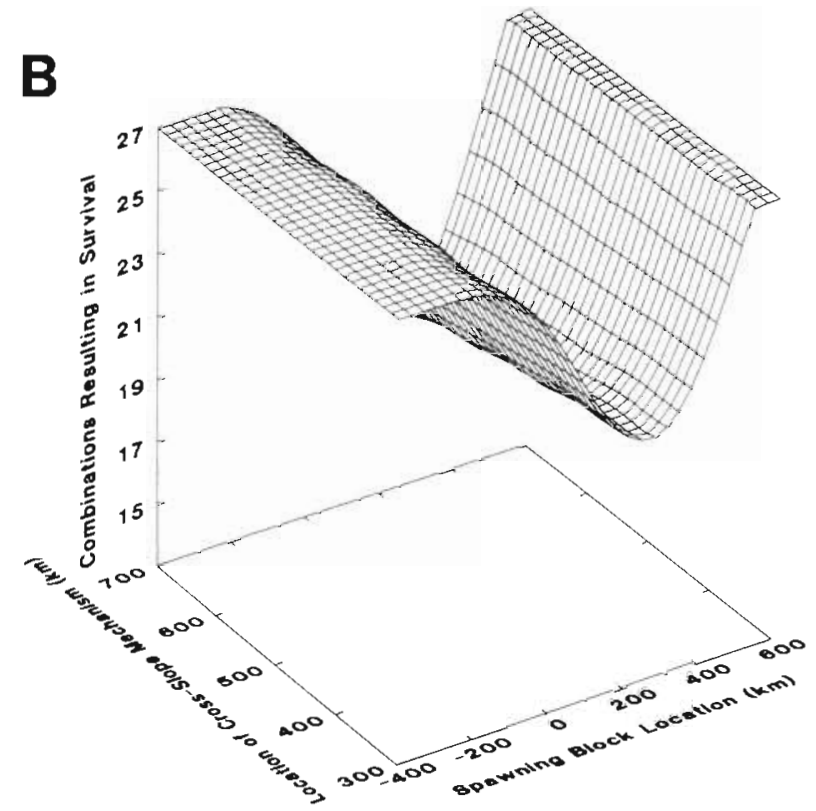

Fig. 9. Three-dimensional representation of the second and third runs of the transport model. (A) For the second model run spawning location is on the $x$-axis, 'survival age' is on the $y$-axis and the number of transport speed combinations of the 3 components resulting in 'survival' is on the $z$-axis (maximum $=27$ ). Distance to the cross-slope component was set at $444 \mathrm{~km}$. (B) For the third model run the $x$-and $z$-axes are the same as for the second model run and the $y$-axis is the location of the cross-slope transport component. 'Survival age' was set at $60 \mathrm{~d}$. A surface has been fitted to the model's results using distance-weighted least squares

\section{DISCUSSION}

\section{Ecological aspects of larval transport}

Our model demonstrates that transport processes are a viable mechanism through which a bimodal recruitment pattern of juvenile bluefish could be created from a continuous and protracted spawning. Our model's results, however, are in a spatial framework and it is necessary to translate these spatial results into predictions regarding the temporal pattern of recruitment probability. Once translated, the model's predictions can be examined in terms of the observed patterns of estuarine recruitment. Such an examination may provide insights into the actual transport of bluefish offspring and into transport as a process that creates intra- and interannual recruitment variability.

Several studies have shown that recruitment of June-spawned individuals is consistently low, while recruitment of July - and August-spawned individuals is variable, both on intra- and interannual scales (Nyman \& Conover 1988, McBride \& Conover 1991). Our model predicts that estuarine recruitment of Junespawned fish will be consistently low because a large portion of these individuals are spawned in the southern MAB (Figs. 4 \& 5), an area for which the probability of being incorporated into the Gulf Stream and removed from the shelf is high. In July and August, however, most offspring are spawned north of Delaware Bay (Figs. $4 \& 5$ ), an area for which the model predicts recruitment probability to be variable, depending upon the along-shelf transport speed. This indicates that the intra- and interannual variability in recruitment of July- and August-spawned bluefish may be due to weekly, monthly and annual variations in along-shelf flow.

While the average along-shelf current in the MAB is towards the southwest at velocities of 5 to $10 \mathrm{~cm} \mathrm{~s}^{-1}$, there are periods of greater southwest speeds and periods of northeastward current reversals. This variability is greatest in the summer due to water column stratification (Epifanio et al. 1989, Flagg et al. in press) and is influenced by wind events (Bumpus 1969, Scott \& Csanady 1976, Epifanio et al. 1989), local freshwater input (Bumpus 1969, Manning 1991), and input from the coastal current system (Chapman \& Beardsley 1989, Mountain 1991). Greater along-shelf current speeds would effectively flush the MAB, transporting more offspring into the slope and reducing recruitment probability. Current reversals, on the other hand, would retain offspring within the MAB and enhance recruitment probability (Epifanio et al. 1989)

For offspring spawned in the SAB, the model predicted high recruitment probability. Birthdates of estuarine bluefish, however, demonstrate that recruitment of May-spawned offspring, which are predominantly 
spawned in the northern half of the SAB (Figs. 4 \& 5), is consistently low. This lack of correspondence between predicted and observed recruitment patterns for May-spawned bluefish suggests that our understanding of the transport of SAB-spawned bluefish is incomplete. Bluefish spawn on the outer portion of the $\mathrm{SAB}$ shelf making larvae susceptible to northeastward transport associated with the Gulf Stream (Kendall \& Walford 1979, Collins \& Stender 1987). South Atlantic Bight shelf water is incorporated into Gulf Stream associated flows (Churchill et al. unpubl.), but the temporal and spatial frequency of these events are not well documented. Additionally, the velocity of entrained $\mathrm{SAB}$ water has not been directly measured. Understanding the mechanism of incorporation, its frequency and the volume of water involved are all very important to understanding larval transport of bluefish, as well as other species which are transported off the $S A B$ shelf and northeastward in association with the Gulf Stream (e.g. Xyrichtys novacula, Bothus sp., Syacium papillosum, Ioglossus calliurus; Hare \& Cowen 1991, Cowen et al. in press).

There are similar gaps in our knowledge regarding the mechanisms of cross-slope transport. The model used cross-slope transport speeds which represented 2 previously identified crossing mechanisms: warmcore ring streamers and active swimming behavior. At transport speeds representative of warm-core ring streamers (ca 40 to $50 \mathrm{~cm} \mathrm{~s}^{-1}$ ), the model predicted that recruitment of SAB-spawned fish would be high. The model specified, however, that all offspring would be transported by the cross-slope component, but warmcore ring streamers are known to be temporally and spatially patchy (Hare \& Cowen 1991, Cowen et al. in press). Therefore, if streamers are the mechanism by which bluefish cross the slope, this would add to intraand interannual recruitment variability. In terms of consistently low recruitment of May-spawned fish, however, there is no a priori reason to expect that streamers would be more available to April-spawned fish as compared to May-spawned fish. What is needed is an interannual comparison of warm-core ring streamer activity and bluefish recruitment, to test for a link between warm-core ring streamers and recruitment of SAB-spawned bluefish to MAB estuaries

Active swimming behavior is another potential crossing mechanism, and the model predicts that at transport speeds equivalent to expected swimming speeds ( 2 to 3 body lengths $\mathrm{s}^{-1}$; Hunter 1981), there would be a decrease in recruitment probability from Cape Fear, North Carolina to Montauk Point, New York with the lowest survival in the area between Chesapeake Bay and Delaware Bay (Fig. 8C). Translating this result into temporal terms, recruitment probability would be high from March to April when most offspring are spawned south of Cape Fear (Figs. 4 \& 5). Recruitment probability would also be high from July to August when many offspring are spawned north of Delaware Bay (Figs. 4 \& 5). Low recruitment, on the other hand, would be expected from May to June when a majority of offspring are spawned from Cape Fear to Delaware Bay (Figs. 4 \& 5). Therefore, considering swimming as the crossing mechanism, the recruitment pattern predicted by the model matches the actual recruitment pattern observed in MAB estuaries.

This match between the model's results and the observed recruitment patterns indicates that swimming must be seriously considered as a transport mechanism in these fish. Since swimming ability is related to size (Hunter 1981), individuals may need to grow to a certain size before the initiation of swimming behavior in order to make it across the slope. In addition, as bluefish spawning nears Cape Hatteras from the south, offspring may be transported too far to the east before swimming behavior develops. An individual's location when swimming behavior is initiated will also depend on the past transport speed. Thus, the interaction between development time, initiation of swimming behavior, spawning location and pre-swimming transport speed need to be considered in terms of recruitment success of bluefish incorporated into Gulf Stream associated flows. These interactions may also be important in recruitment success of other species which apparently cross the slope to the MAB shelf edge and ultimately coastal habitats (e.g. Anguilla rostrata, Urophycis tenuis).

\section{Evolutionary considerations of reproductive strategy}

In this study we propose that bluefish spawn continuously and over a protracted period, rather than in 2 distinct episodes as suggested previously (Kendall \& Walford 1979, Chiarella \& Conover 1990). Our alternative hypothesis regarding bluefish reproductive strategy is contrary to the ideas of Parrish et al. (1981), who concluded that reproductive strategies of fishes in the California Current have adapted to the general flow characteristics of the region. For bluefish, this adaptationist viewpoint would predict that since there is a regular annual pattern in offspring survival, spawning should occur in 2 distinct episodes to match this survival. This prediction could be used as an explanation for the two-spawning hypothesis, however, based on our hypothesis, offspring are produced at times for which recruitment is predictably low due to characteristics of the large-scale physical environment. Bluefish reproductive strategy, therefore, may not appear to be well adapted to the present-day physical environment. 
There are a variety of explanations for the possible non-adaptive nature of bluefish reproductive strategy. One explanation is that bluefish are 'bet-hedging'; the parental investment required to produce planktonic offspring is small, so that even the slightest probability of survival outweighs the cost of offspring production (Stearns 1976). Another possibility is that this reproductive pattern is a result of phylogenetic history; at some point in bluefish phylogeny continuous spawning evolved and has since remained static. This hypothesis can in theory be examined by developing a phylogeny including various bluefish populations and presumed sister groups, the genus Scombrops, scombrids and carangids (van der Elst 1976, Wilk 1977), and mapping reproductive strategy onto this phylogeny (see Brooks \& McLennan 1991).

In addition to these biological explanations, it is possible that bluefish reproductive strategy is not presently adaptive due to recent geological changes in the environment. During the past 1.6 millon years, as many as 30 glacial episodes have occurred with corresponding changes in sea level (Kennett 1982). These episodes have altered both biogeographic (Berggren \& van Couvering 1979, Moore et al. 1981) and circulation patterns (Broecker \& Denton 1989), and have had their greatest effect on the temperate regions $\left(35\right.$ to $60^{\circ} \mathrm{N}$ ) of the North Atlantic (McIntyre et al. 1976). During the most recent glacial period, sea level was ca 80 to $100 \mathrm{~m}$ lower than at present (Kennett 1982), meaning that the eastern United States continental shelf habitat was narrower compared to present conditions (ca 20 to $80 \mathrm{~km}$ compared to 40 to $180 \mathrm{~km}$ currently). South of Cape Hatteras, the Gulf Stream followed the shelf break, as it does presently, but at Cape Hatteras the flow turned due east resulting in the transport of tropical organisms much further into the Atlantic than observed during interglacial periods (CLIMAP 1976). Summer sea surface temperatures north of Cape Hatteras were 6 to $10^{\circ} \mathrm{C}$ cooler, while south of approximately Cape Canaveral, Florida, they were less than $2{ }^{\circ} \mathrm{C}$ cooler (McIntyre et al. 1976).

It is likely that these glacial-interglacial changes have influenced the ecology and evolution of bluefish in the western North Atlantic. The species range of bluefish has probably shifted north and south in relation to the proximal cues of glacial-interglacial temperature differences. During glacial periods, bluefish were probably restricted to an area south of Cape Hatteras and spawning would have occurred completely in an area swept by a strong western boundary current. During interglacial periods, bluefish were probably seasonally distributed both south and north of Cape Hatteras. Spawning in this case would have occurred in a region affected by the Gulf Stream and in an area of counter flowing shelf currents. Bluefish re- productive strategy, therefore, would not necessarily be expected to be adapted to the present day environment due to the availability of the MAB only during interglacial periods. The problem becomes how quickly can reproductive strategy evolve in relation to the rate of large-scale environmental change.

The MAB as a geologically periodic environment is not only relevant to bluefish reproductive strategy and larval transport, but is also important to an entire pelagic ichthyofauna which uses the MAB during periods of warm temperature for feeding and/or spawning. This pelagic fauna includes bluefish, butterfish Peprilus triacanthus, jacks (Caranx spp., Decapterus spp., Seriola spp.), dolphinfish Coryphaena spp., mackerel Scomber scombrus, swordfish Xiphias gladius and tunas (Auxis spp., Scomberomorus maculatus, Thunnus spp.). For one of these species, butterfish, a bimodal birthdate distribution of juveniles has been found (Rotunno 1992, Cowen \& Rotunno unpubl. data), raising potential parallels with our ideas regarding bluefish reproduction and larval transport. The largescale circulation of the eastern coast of the United States, both presently and geologically, will affect all species and we might expect more reproductive and transport parallels between species which are using similar adult, as well as pre-adult habitats

Throughout most of this discussion, reproductive strategy and offspring transport have been considered separately, but they are actually interrelated. The transport of offspring is not solely a passive process, but involves physically forced movement, offspring behavior (Kelly et al. 1982, Rothlisburg 1982) and adult spawning behavior (Christy 1982, Checkley et al. 1988). Thus, reproduction plays an integral role in transport through the initial spatial and temporal placement of offspring. Transport, on the other hand, plays a role in the evolution of reproductive strategy, for it is involved in shaping offspring survival patterns. An understanding of actual transport can lead to evolutionary questions regarding reproductive strategy, life history and population structure (Rosenblatt \& Waples 1986, Thresher \& Brothers 1989, Bowen \& Avise 1990). Therefore, once physical movement, offspring behavior and reproductive strategy are considered together and within a historical framework, we can begin to understand the actual role of transport in shaping planktonic survival and life histories of marine organisms.

Acknowledgements. We thank all those who have contributed to this work. Critical reviews of this manuscript were provided by Jim Churchill, Dave Conover, Ed Houde, Francis Juanes, Art Kendall, Rich McBride, Steve Morgan and 2 anonymous referees. We thank them for their time and efforts. Our ideas regarding bluefish life history have benefitted from conversations with Lou Chiarella, Dave Conover, Mike 
Fahay, Francis Juanes, Art Kendall, Rich McBride, Eric Schultz, Michiyo Shima and Su Sponaugle. Bill Showers introduced us to the paleoceanographic literature. Charlie Flagg and Rich McBride provided us with their papers in press. Lastly, John Finucane, Alan Collins, Tom Potthoff and Bruce Stender provided us with unpublished materials and in Bruce Stender's case all the South Atlantic Bight MARMAP bluefish for our examination. This study would not have been possible without their assistance. This work was sponsored by the NOAA Office of Sea Grant, U.S. Dept of Commerce, under Grants \#NA86AA-D-SG045 and \#NA90AA-D-SG078 to the New York Sea Grant Institute, by the New York Dept of Environmental Conservation through the Dingell-Johnson Federal Aid in Sport-Fish Restoration, by the Sounds Conservancy through their Marine Conservation Education and Research for the Marine Region of Southern New England granting program and by the Living Marine Resources Institute of the Marine Sciences Research Center State University of New York at Stony Brook. This is contribution number 907 of the Marine Sciences Research Center.

\section{LITERATURE CITED}

Beardsley, R. C., Boicourt, W. C., Hansen, D. V. (1976). Physical oceanography of the Middle Atlantic Bight. Am. Soc. Limnol. Oceanogr. Spec. Symp. 2: 20-33

Beardsley, R. C., Chapman, D. C., Brink, K. H., Ramp, S. R., Schlitz, R. (1985). The Nantucket Shoals Flux Experiment (NSFE79). Part I: A basic description of the current and temperature variability. J. phys. Oceanogr. 15: 713-748

Berggren, W. A., van Couvering, J. A. (1979). Quaternary. In: Robinson, R. A., Teichert, C. (eds.) Treatise on invertebrate paleontology. Geological Association of America, Lawrence, KS, p. A.505-A.543

Bigelow, H. B., Schroeder, W. C. (1953). Fishes of the Gulf of Maine. Fish. Bull. U.S. 53: 1-577

Bowen, B. W., Avise, J. C. (1990). Genetic structure of Atlantic and Gulf of Mexico populations of sea bass, menhaden, and sturgeon: influence of zoogeographic factors and lifehistory patterns. Mar. Biol. 107: 371-381

Briggs, J. C. (1960). Fishes of worldwide (circumatropical) distribution. Copeia 1960: 171-180

Broecker, W. S., Denton, G. H. (1989). The role of ocean-atmosphere reorganizations in glacial cycles. Geochim Cosmochim. Acta 53: 2465-2501

Brooks, D. R., McLennan, D. A. (1991). Phylogeny, ecology, and behavior. Chicago University Press, Chicago

Brown, O. B., Cornillon, P. C., Emmerson, S. R., Carle, H. M (1986). Gulf Stream warm rings: a statistical study of their behavior. Deep Sea Res. 33: 1459-1473

Bumpus, D. F. (1969). Reversals in the surface drift in the Middle Atlantic Bight. Deep Sea Res. 16 (suppl.): $17-23$

Chapman, D. C., Beardsley, R. C. (1989). On the origin of shelf water in the Middle Atlantic Bight. J. phys. Oceanogr. 19: 384-391

Checkley, D. M., Raman, S., Maillet, G. L., Mason, K. M. (1988). Winter storm effects on the spawning and larval drift of a pelagic fish. Nature 335: 346-348

Chiarella, L. A., Conover, D. O. (1990). Spawning season and first-year growth of adult bluefish from the New York Bight. Trans. Am. Fish. Soc. 119:455-462

Christy, J. H. (1982). Adaptive significance of semilunar cycles of larval release in fiddler crabs (genus $U_{C a}$ ): a test of an hypothesis. Biol. Bull. 163: 251-263

Churchill, J. H., Cornillon, P. C., Hamilton, P. (1989). Velocity and hydrographic structure of subsurface shelf water at the Gulf Stream's edge. J. geophys. Res. 94: 10791-10800

Clark, J., Smith, W. G., Kendall, A. W., Fahay, M. P. (1969). Studies of estuarine dependence of Atlantic coastal fishes. Data Report 1: northern section, Cape Cod to Cape Lookout. RV 'Dolphin' cruises 1965-1966: zooplankton volumes, midwater trawl collections, temperatures and salinities. Tech. Pap. Bur. Sport Fish. Wildl. U.S. 28: 1-132

Clark, J., Smith, W. G., Kendall, A. W., Fahay, M. P. (1970). Studies of estuarine dependence of Atlantic coastal fishes. Data Report II: southern section, New River Inlet, N. C., to Palm Beach, Fla. RV 'Dolphin' cruises 1967-1968: zooplankton volumes, surface-meter net collections, temperatures and salinities. Tech. Pap. Bur. Sport Fish. Wildl. U.S. 59: $1-97$

CLIMAP. (1976). The surface of the ice-age earth. Science 191: 1131-1137

Collins, M. R., Stender, B. W. (1987). Larval king mackerel (Scomberomorus cavalla), spanish mackerel (S. maculatus), and bluefish (Pomatomus saltatrix) off the southeast coast of the United States, 1973-1980. Bull. mar. Sci. 41: 822-834

Cowen, R. K. (1985). Large scale pattern of recruitment by the labrid, Semicossyphus pulcher. causes and implications. J. mar. Res. 43: 719-742

Cowen, R. K., Hare, J. A., Fahay, M. P. (in press). Beyond hydrography: can physical processes explain larval fish assemblages within the Middle Atlantic Bight. 15th Annual Larval Fish Conference Special Symposia. Bull mar. Sci.

Csanady, G. T., Hamilton, P. (1988). Circulation of slopewater Cont. Shelf Res. 8: 565-624

de Sylva, D. P., Kalber, F. A., Shuster, C. N. (1962). Fishes and ecological conditions in the shore zone of the Delaware River estuary, with notes on other species collected in deeper water. Univ. Del. mar. Lab. Inf. Ser. Publ. No. 5: $1-164$

Deuel, D. G., Clark, J. R., Mansueti, A. J. (1966). Description of embryonic and early larval stages of bluefish, Pomatomus saltatrix. Trans. Am. Fish. Soc. 95: 264-271

DeVlaming, V., Grossman, G., Chapman, F. (1982). On the use of gonosomatic index. Comp. Biachem. Physiol. 73A: $31-39$

Epifanio, C. E., Masse, A. K., Garvine, R. W. (1989). Transport of crab larvae by surface currents off Delaware Bay, USA. Mar. Ecol. Prog. Ser. 54: 35-41

Fisher, A. (1972). Entrainment of shelf water by the Gulf Stream northeast of Cape Hatteras. J. geophys. Res. 77 : $3248-3255$

Flagg, C. N., Houghton, R. W., Pietrafesa, L. J (in press) Summertime thermocline and sub-thermocline crossfrontal intrusions in the Mid-Atlantic Bight. Cont. Shelf Res.

Ford, W. L., Longard, J. R., Banks, R. E. (1952). On the nature, occurrence and origin of cold low salinity water along the edge of the Gulf Stream. J. mar. Res. 11: 281-293

Gaines, S., Roughgarden, J (1987). Fish in offshore kelp forests affect recruitment to intertidal barnacle populations. Science 235: 479-481

Harden-Jones, F. R. (1968). Fish migration. Edward Arnold, London

Hardy, J. D. (1978). Development of fishes of the mid-Atlantic Bight, an atlas of egg, larval and juveniles stages. Vol. III A phredoderidae through Rachycentridae. U.S. Fish. Wildl Serv. Biol. Serv. Program FWS/OBS-78/12

Hare, J A., Cowen, R. K. (1991). Expatriation of Xyrichtys novacula (Pisces: Labridae) larvae: evidence of rapid cross-slope exchange. J. mar. Res. 49: 801-823 
Haury, L. R., McGowan, J. A., Wiebe, P. H. (1978). Patterns and processes in the time-space scales of plankton distribution. In: Steele, J. (ed.) Spatial pattern in plankton communities. Plenum Press, New York, p. 277-327

Hjort, J (1914). Fluctuations in the great fisheries of Northern Europe. Rapp. P.-v, Réun. Cons. int. Explor Mer 20 $1-228$

Hunter, J. R. (1981). Feeding ecology and predation of marine fish larvae. In: Lasker, R. (ed.) Marine fish larvae: morphology, ecology, and relation to fisheries. Washington Sea Grant Program, Seattle, p. 34-77

Iles, T. D., Sinclair, M. (1982). Atlantic herring: stock discreteness and abundance. Science 215:627-633

Jackson, G. A., Strathmann, R. R. (1981). Larval mortality from offshore mixing as a link between precompetent and competent periods of development. Am. Nat. 118:16-26

Joyce, T. M., Kelly, K. A., Schubert, D. M., Caruso, M. J. (1990). Shipboard and altimetric studies of rapid Gulf Stream variability between Cape Cod and Bermuda. Deep Sea Res. 37: 897-910

Kelly, P., Sulkin, S. D., van Heukelem, W. F. (1982). A dispersal model for larvae of the deep sea red crab Geryon quinquedens based on behavioral regulation of vertical migration in the hatching stage. Mar. Biol. 72: 35-43

Kendall, A. W., Walford, L. A. (1979). Sources and distributions of bluefish. Pomatomus saltatrix, larvae and juveniles off the east coast of the United States. Fish. Bull. U.S. $77: 213-227$

Kennett, J. P. (1982). Marine geology. Prentice-Hall Englewood Cliffs

Lasker, R. (1975). Field criteria for survival of anchovy larvae: the relation between inshore chlorophyll maximum layers and successful first feeding. Fish. Bull. U.S. 73 $453-462$

Lasker, R. (1978). The relation between oceanographic conditions and larval anchovy food in the California current identification of factors contributing to recruitment failure. Rapp. P.-v. Réun. Cons. int. Explor. Mer 173: 212-230

Lillibridge, J. L., Hitchcock, G., Rossby, T., Lessard, E., Mork, M., Golmen, L. (1990). Entrainment and mixing of shelf/slope waters in the near surface Gulf Stream. J. geophys. Res. 95: 13065-13087

Lund, W. A. (1961). A racial investigation of the bluefish, Pomatomus saltatrix (Linnaeus) of the Atlantic coast of North America. Bol. Inst. Oceanogr. Univ. Oriente 1: $73-129$

Manning, J. (1991). Middle Atlantic Bight salinity: interannual variability. Cont. Shelf Res. 11: 123-137

McBride, R. S. (1989). Comparative growth and abundance of spring-versus summer-spawned young-of-the-year bluefish, Pomatomus saltatrix, recruiting to the New York Bight. M.Sc thesis, State University of New York at Stony Brook

McBride, R. S., Conover, D. O. (1991). Recruitment of youngof-the-year bluefish Pomatomus saltatrix to the New York Bight: variation in abundance and growth of spring- and summer-spawned cohorts. Mar. Ecol. Prog. Ser 78: $205-216$

McBride, R. S., Ross, J. L., Conover, D. O. (in press). Recruitment of bluefish (Pomatomus saltatrix) to estuaries of the South Atlantic Bight. Fish. Bull. U.S.

McIntyre, A., Kipp, N. G., Be, W. H., Crowley, T., Kellogg, T., Gardner, J. V., Prell, W., Ruddiman, W. F. (1976). Glacial North Atlantic 18,000 years ago: a CLIMAP reconstruction. In: Cline, R., Hays, J. (ed.) Investigations of late quaternary paleoceanography and paleoclimatology. Geol. Soc. Am. Mem. 145: 43-76
Methot, R. D. (1983). Seasonal variation in survival of larval Engraulis mordax estimated from the age distribution of juveniles. Fish. Bull. U.S. 81: 741-750

Moore, T C., Hutson, W. H1., Kipp, N., Hays, J. D., Prell, W., Thompson, P., Boden, G. (1981). The biological record of the ice-age ocean. Paleogeogr. Paleoclimatol. Paleoecol. 35: $357-370$

Morse, W. W., Fahay, M. P., Smith, W. G. (1987). MARMAP surveys of the continental shelf from Cape Hatteras, North Carolina to Cape Sable, Nova Scotia (1977-1984). Atlas No. 2. Annual distribution patterns of fish larvae. NOA.A Tech. Mem. NMFS-F/NEC-47

Mountain, D. G. (1991). The volume of shelf water in the Middle Atlantic Bight: seasonal and interannual variability, 1977-1987. Cont. Shelf Res. 11. 251-267

Nichols, J. T., Breder, C. M. (1926). The marine fishes of New York and southern New England. Zoologica 1. 1-192

Norcross, J. J., Richardson, S. L., Massmann, W. H., Joseph, E. B. (1974). Development of young bluefish (Pomatomus saltatrix) and distribution of eggs and young in Virginian coastal waters. Trans. Am. Fish. Soc. 103: 477-497

Nyman, R. M. (1987). The relation between oceanic spawning season and recruitment of juvenile bluefish, Pomatomus saltatrix, to New York waters. M.Sc. thesis, State University of New York at Stony Brook

Nyman, R. M., Conover, D. O. (1988). The relation between spawning season and the recruitment of young-of-theyear bluefish, Pomatomus saltatrix, to New York. Fish. Bull. U.S. 86: 237-250

Parrish, R. H., Nelson, C. S., Bakun, A. (1981). Transport mechanisms and reproductive success of fishes in the California Current. Biol. Oceanogr 1: 175-203

Pierce, S. D., Joyce, T M. (1988). Gulf stream velocity structure through inversion of hydrographic and acoustic doppler data. J. geophys. Res. 93: 2227-2236

Powles, H., Stender, B. W. (1976). Observations on the composition, seasonality and distribution of ichthyoplankton from MARMAP cruises in the South Atlantic Bight in 1973. Tech. Rep. So. Car. Mar. Res. Cent. 11. 1-47

Rosenblatt, R. H., Waples, R. S. (1986). A genetic comparison of allopatric populations of shore fishes from the eastern and central Pacific Ocean: dispersal or vicariance. Copeia 1986: $275-284$

Rothlisburg, P. C. (1982). Vertical migration and its effect on dispersal of panaeid shrimp larvae in the Gulf of Carpentaria, Australia. Fish. Bull. U.S. 80: 541-554

Rothschild, B. J. (1986). Dynamics of marine fish populations. Harvard University Press, Cambridge

Rotunno, T (1992). Species identification and temporal spawning patterns of butterfish, Peprilus spp., in the South and Middle A.tlantic Bights. M.Sc. thesis, State University of New York at Stony Brook

Roughgarden, J., Gaines, S., Possingham, H. (1988). Recruitment dynamics in complex life cycles. Science 241: $1460-1466$

Scott, J. T., Csanady, G. T. (1976). Nearshore currents off Long Island. J. geophys. Res. 81: 5401-5409

Shima, M. (1989). Oceanic transport of the early life history stages of bluefish (Pomatomus saltatrix) from Cape Hatteras to the Mid-Atlantic Bight. M.Sc. thesis, State University of New York at Stony Brook

Sibunka, J. D., Silverman, M. J. (1984). MARMAP surveys of the continental shelf from Cape Hatteras, North Carolina, to Cape Sable, Nova Scotia (1984-1987). Atlas No. 1. Summary of operations. NOAA Tech. Mem. NMFSF/NEC-33

Sibunka, J. D., Silverman, M. J. (1989). MARMAP surveys of 
the continental shelf from Cape Hatteras, North Carolina, to Cape Sable, Nova Scotia (1984-1987). Atlas No. 3. Summary of operations. NOAA Tech. Mem. NMFSF/NEC-68

Sinclair, M. (1988). Marine populations: an essay on population regulation and speciation. Washington Sea Grant Program, Seattle

Stearns, S. C. (1976). Life history tactics: a review of ideas. Q. Rev. Biol. 51:3-47

Stommel, H. (1963). Varieties of oceanographic experience. Science 139: 572-576

Strathmann, R. R. (1982). Selection for retention or export of larvae in estuaries. In: Kennedy, V. (ed.) Estuarine comparisons. Academic Press, New York, p. 521-536

Thresher, R. E., Brothers, E. B. (1989). Evidence of intra- and

This article was submitted to the editor inter-oceanic regional differences in the early life history of reef-associated fishes. Mar. Ecol. Prog. Ser. 57: 187-205

van der Elst, R. (1976). Game fish of the east coast of southern Africa. I. The biology of the elf Pomatomus saltatrix (Linnaeus), in the coastal waters of Natal. Oceanogr. Res. Inst. (Durban) Invst. Rep. 44:1-59

Victor, B. C. (1986). Larval settlement and juvenile mortality in a recruitment limited coral reef fish population. Ecol. Monogr. 56: 145-160

Wilk, S. J. (1977). Biological and fishery data on bluefish, Pomatomus saltatrix (Linnaeus). NMFS-NEFC Sandy Hook Lab. Tech. Ser. Rep. 11

Yoshioka, P. M. (1986). Chaos and recruitment in the bryozoan, Membranipora membranacea. Bull. mar. Sci. 39: $408-417$

Manuscript first received: November 27, 1992 Revised version accepted: April 1, 1993 